University of Nebraska - Lincoln

DigitalCommons@University of Nebraska - Lincoln

7-1998

\title{
Inheritance and QTL Analysis of Field Resistance to Ashy Stem Blight in Common Bean
}

\author{
Phillip N. Miklas \\ USDA-ARS, phil.miklas@ars.usda.gov \\ Valerie Stone \\ Whitehead Institute \\ Carlos A. Urrea \\ University of Nebraska-Lincoln, currea2@unl.edu \\ E. Johnson \\ North Carolina State University \\ James S. Beaver \\ University of Puerto Rico, james.beaver@upr.edu
}

Follow this and additional works at: https://digitalcommons.unl.edu/panhandleresext

Miklas, Phillip N.; Stone, Valerie; Urrea, Carlos A.; Johnson, E.; and Beaver, James S., "Inheritance and QTL Analysis of Field Resistance to Ashy Stem Blight in Common Bean" (1998). Panhandle Research and Extension Center. 91.

https://digitalcommons.unl.edu/panhandleresext/91

This Article is brought to you for free and open access by the Agricultural Research Division of IANR at DigitalCommons@University of Nebraska - Lincoln. It has been accepted for inclusion in Panhandle Research and Extension Center by an authorized administrator of DigitalCommons@University of Nebraska - Lincoln. 


\title{
Inheritance and QTL Analysis of Field Resistance to Ashy Stem Blight in Common Bean
}

\author{
Phillip N. Miklas, ${ }^{*}$ Valerie Stone, Carlos A. Urrea, E. Johnson, and James S. Beaver
}

\begin{abstract}
Ashy stem blight [caused by Macrophomina phaseolina (Tassi) Goid.] can be a serious disease of common bean (Phaseolus vulgaris L.) under drought and high temperature conditions in some regions. The mode of inheritance of valuable sources of resistance is lacking. We studied inheritance of field resistance to ashy stem blight in a recombinant inbred population ('Dorado' $\times$ XAN 176) consisting of $119 \mathrm{~F}_{5: 7}$ recombinant inbred lines (RILs) tested in replicated experiments across 2 yr. A score from 1 to 9 (no disease to severe disease) was used to measure disease reaction. Moderate $H_{\mathrm{Ns}}(0.53$ and 0.57$)$ and near-normal frequency distribution of RILs for mean disease score each year indicated a lack of discrete segregation classes. The phenotypic variation across a subgroup composed of 79 RILs was further investigated with 165 randomly amplified polymorphic DNA (RAPD) markers by one-way analyses of variance and interval mapping. Five quantitative trait loci (QTL), explaining 19, 15, 15, 13, and $13 \%$ of the phenotypic variation for disease score, were detected in 1993. Three of these QTL, explaining 15, 12, and $12 \%$ of the variation in disease reaction, were detected in 1994. Multiple QTL regression models $(P<0.01$ ) explained up to $47 \%$ (four loci) of the phenotypic variation for disease score in 1993 and $28 \%$ (three loci) in 1994. The five QTL, all derived from XAN 176, generally showed additive effects. These QTL-linked RAPD markers may prove useful for indirect selection of field resistance to ashy stem blight derived from XAN 176.
\end{abstract}

$\mathrm{A}^{\mathrm{s}}$ SHY STEM BLIGHT or charcoal rot, incited by Macrophomina phaseolina, is a serious disease of common bean in tropical and subtropical areas and some temperate regions characterized by high temperatures and drought conditions. Zaumeyer and Thomas (1957) reported $65 \%$ yield reduction in common bean from ashy stem blight in the USA, and Miklas et al. (1998b) observed disease severity was correlated with yield loss in tepary bean (Phaseolus acutifolius A. Gray latifolius G. Freeman). Periodic ashy stem blight epidemics of common bean occur in Puerto Rico (Echavez-Badel and Beaver, 1987). In addition to common bean, this fungus can inflict substantial yield loss on other crops (Schwartz, 1989) such as soybean [Glycine max (L.) Merr.], maize (Zea mays L.), and sorghum [Sorghum bicolor (L.) Moench]. Pastor-Corrales and Abawi (1988) report that losses in common bean result from either preemergence and postemergence death of seedlings (seedling rot disease) or reduced vigor and yield of adult plants (ashy stem blight disease). The pathogen is seed transmissible (Abawi and Pastor-Corrales, 1990b), but primary inoculum causing epidemics are

P.N. Miklas, USDA-ARS-IAREC, 24106 N. Bunn Rd., Prosser, WA 99350-9687; V. Stone, Whitehead Institute, 9 Cambridge Center, Cambridge, MA 02142; C.A. Urrea, Dep. of Plant Sciences, North Dakota State Univ., Fargo, ND 58105; E. Johnson, Crop Science Dep., North Carolina State Univ., Raleigh, NC 27695; J.S. Beaver, Dep. of Agronony and Soils, Univ. of Puerto Rico, Mayagüez, PR 00681. Received 3 March 1997. *Corresponding author (pmiklas@tricity.wsu.edu).

Published in Crop Sci. 38:916-921 (1998). sclerotia embedded in organic debris or free in the soil. Crop rotation is recommended as an integrated control practice to reduce inoculum in the soil.

Genetic resistance to $M$. phaseolina is also advocated for integrated control practices, and high levels of resistance have been observed in beans (Echavez-Badel and Beaver, 1987; Pastor-Corrales and Abawi, 1988). The combining of resistances from different sources will likely provide more durable resistance. Olaya et al. (1996) determined in greenhouse inoculations that resistance of BAT 477 was conditioned by two dominant complementary genes, $M p-1$ and $M p$-2. However, a direct relationship between $M p-1$ and $M p-2$ and field resistance exhibited by BAT 477 (Pastor-Corrales and Abawi, 1988) was not shown. Some researchers (Beebe and Pastor-Corrales, 1991; Pastor-Corrales and Abawi, 1988) allude to, or report, strong correlations between field and greenhouse reactions to ashy stem blight, whereas, Miklas et al. (1998b) working with tepary bean observed none. Perhaps the greenhouse method used by Miklas et al. (1998b) selectively measured resistance to seedling rot (Abawi and Pastor-Corrales, 1989) but not adult-plant resistance to ashy stem blight in the field. Additional information concerning inheritance of field resistance is needed to enhance breeding efforts. Herein, field resistance to ashy stem blight in a recombinant inbred population (Dorado/XAN-176) is investigated by means of multiple environments and a linkage map for identifying putative QTL.

\section{MATERIALS AND METHODS}

A recombinant inbred population of 119 randomly derived $F_{5: 7}$ lines (RILs) generated from a Dorado (formerly DOR 364) $\times$ XAN 176 hybridization was evaluated for field reaction to ashy stem blight at the University of Puerto Rico, Fortuna Substation at Juana Díaz, PR, (fine-loamy, mixed, isohyperthermic Cumulic Haplustoll) during the summers of 1993 and 1994. Ashy stem blight epidemics frequently occur in Fortuna because of prevailing high temperatures and low rainfall (Abawi and Pastor-Corrales, 1990a). In addition, the plantings of dry bean on the same experimental area for many years preceding this research likely resulted in elevated soil inoculum levels.

The $F_{5: 7}$ lines were randomly assigned to three separate groups, two of 40 and one of 39 lines. Each year, each group was sown as a separate randomized complete block design with three replications. The groups were planted side by side, and each group contained the parents. Plots consisted of single $1-\mathrm{m}$ rows spaced $80 \mathrm{~cm}$ apart in 1993 and $160 \mathrm{~cm}$ apart in 1994. Plots were rated for ashy stem blight infection at the end of the R-8 growth stage with a 1-to-9 scale similar to CIAT's (Schoonhoven and Pastor-Corrales, 1987). The scale combined incidence (number of plants infected) and severity (plant area affected by the pathogen) of infection on a whole

Abbreviations: cM, centimorgans; DAP, days after planting; $\mathrm{H}_{\mathrm{NS}}$, narrow-sense heritability; QTL, quantitative trait loci (locus); RAPD, random amplified polymorphic DNA; RIL, recombinant inbred line. 
plot ( $1 \mathrm{~m}$ of row) basis, where $1=$ no visible symptoms; $3=$ 10 to $20 \%$ of plants infected and/or about $5 \%$ of the total plant area affected by the pathogen; $5=40$ to $50 \%$ of plants infected and/or about $20 \%$ of plant area affected; $7=60$ to $70 \%$ of plants infected and/or about $40 \%$ of plant area affected; and $9=>80 \%$ of the plants infected and/or about $>60 \%$ of the plant area affected. Differences in relative maturity among the RILs, was recorded from $1=$ early to $3=$ late, on a plot basis in 1994. An early maturing line generally reached harvest maturity ( $80 \%$ of pods harvestable) four to eight days earlier than an intermediate (2) and late maturing RIL, respectively.

The error mean squares for disease score from analyses of variance of the groups were homogeneous based on Bartlett's test; therefore, groups were combined to obtain pooled variances. A separate and similar analysis of the parents was conducted. An analysis of variance across years was also conducted. A narrow-sense heritability estimate for disease score was computed with pooled variances on an $\mathrm{F}_{5: 7}$ line-mean basis and corrected for the level of inbreeding (Hallauer and Miranda, 1981). Heritability approximated a narrow-sense estimate $\left(\mathrm{H}_{\mathrm{NS}}\right)$ because coefficients for nonadditive genetic components in the expectation of genetic variance are near zero for $\mathrm{F}_{5: 7}$ lines. Frequency distributions of the RIL means for disease score were tested for normality with the Shapiro and Wilk test statistic $W$ (PROC Univariate, SAS, 1987). A probability of $P<0.001$ was used to indicate lack of fit.

Only two groups, consisting of 79 randomly chosen RILs, were included in the QTL analysis, because a partial RAPD marker linkage map of these 79 RILs was pre-existent (Miklas et al., 1996). The DNA extraction and PCR (polymerase chain reaction) procedures followed those of Miklas et al. (1996) with the exception that no bulked segregant analysis or selective mapping was used. Each of 165 RAPD markers identified between the parents was analyzed by one-way analysis of variance with the disease score means using PROC GLM (SAS, 1987). $F$-tests significant at $P \leq 0.002$ indicated linkage between a RAPD and QTL. Multiple stepwise regression of the independent QTL was conducted, whereby a marker had to be significant at the $15 \%$ probability level for initial entry into the analysis, and be significant at the $5 \%$ level to remain in the model. Two-way analysis (PROC GLM) for epistatic interactions (additive $\times$ additive) were only computed with markers that detected independent QTL in the first-order analysis

The Mapmaker/EXP 3.0 (Lander et al., 1987) computer program was used to obtain a linkage map of the RAPD loci. A pairwise linkage analysis of the RAPD data, imposing a minimum LOD score of 3.8 and maximum distance of 30

Table 1. Heritability $\left(H_{N S}\right)$, mean, and range of disease scores (1-9, where $1=$ no visible disease symptoms and $9=$ severely diseased) observed for 119 F $_{3: 7}$ RILs (Dorado $\times$ XAN 176) screened in 1993 and 1994 for resistance to ashy stem blight in the field at Juana Díaz, PR.

\begin{tabular}{|c|c|c|c|c|c|}
\hline \multirow[b]{2}{*}{ Year } & \multicolumn{2}{|c|}{ Parental means } & \multicolumn{3}{|c|}{ RIL population } \\
\hline & Dorado & XAN 176 & Mean & Range & $\mathbf{H}_{\mathrm{NS}} /(90 \% \mathbf{C I}) \dagger$ \\
\hline & & -1 & ase sco & (1-9) & \\
\hline $\begin{array}{l}1993 \\
1994\end{array}$ & $\begin{array}{l}6.7 \\
6.4\end{array}$ & $\begin{array}{l}3.0 \\
4.3\end{array}$ & $\begin{array}{l}6.0 \\
5.0\end{array}$ & $\begin{array}{l}2.7-9.0 \\
2.0-8.7\end{array}$ & $\begin{array}{l}0.53 /(0.65-0.39) \\
0.57 /(0.67-0.43)\end{array}$ \\
\hline
\end{tabular}

$\dagger$ Exact confidence intervals were calculated according to the procedures of Knapp et al. (1985). The $H_{N S}$ estimated across years was $0.59(0.66-$ 0.44).

$\doteqdot$ Disease score combined incidence and severity where $1=$ no visible symptoms; $5=40$ to $50 \%$ of plants infected and/or about $20 \%$ of plant area affected; and $9=>80 \%$ of the plants infected and/or about $>60 \%$ of the plant area affected. centimorgans (cM), was used to establish the linkage groups (Group command). Three-point and multi-point log-likelihood thresholds (LOD) of 3.0 were used to order the markers (Try, Compare, Three-point, or Order commands) within groups. Centimorgan distances between linked loci were based upon recombination fractions (Kosambi, 1944). Once the map was constructed, interval mapping (QGene; Nelson, 1996) was used to further analyze the QTL detected by regression. An LOD of 2.0 was used as a significance threshold. Multiple QTL on a linkage group were assumed if, while the position of a single QTL was fixed, any additional QTL with a LOD increase of 2.0 above the fixed QTL was observed (Mapmaker EXP 3.0/QTL 1.1).

\section{RESULTS AND DISCUSSION}

Ideal high temperature and dry soil conditions occurred each year for natural ashy stem blight epidemics. Scattered infection was noted at flowering approximately 39 days after planting (DAP). Infection became severe and uniform across the planting by 73 to 75 DAP when disease evaluations were conducted. Typical ashy stem blight symptoms (Abawi and Pastor-Corrales, 1990a) observed included: stems and petioles with bleached and grayish areas, microsclerotia covering plant surfaces, plant chlorosis, wilting, and death. There were no apparent problems with seedling emergence indicating minimal preemergence and postemergence death from seedling rot incited by $M$. phaseolina.

The difference in disease score between the parents was significant both years $(P<0.01$ in 1993 and $P<$ 0.05 in 1994), with XAN 176 being more resistant than Dorado (Table 1). Disease score was negatively correlated on a plot basis with relative maturity measured in 1994 ( $r=-0.59, P<0.01,350 \mathrm{df}$ ). Later maturity has also been associated with resistance to Fusarium root rot [Fusarium solani (Martius) Appel and Wr. f. sp. phaseoli (Burk.) Snyd. and Hans] (Abawi, 1989). In this study, the difference in relative maturity between Dorado (1.7) and XAN 176 (2.0) was slight, so ashy

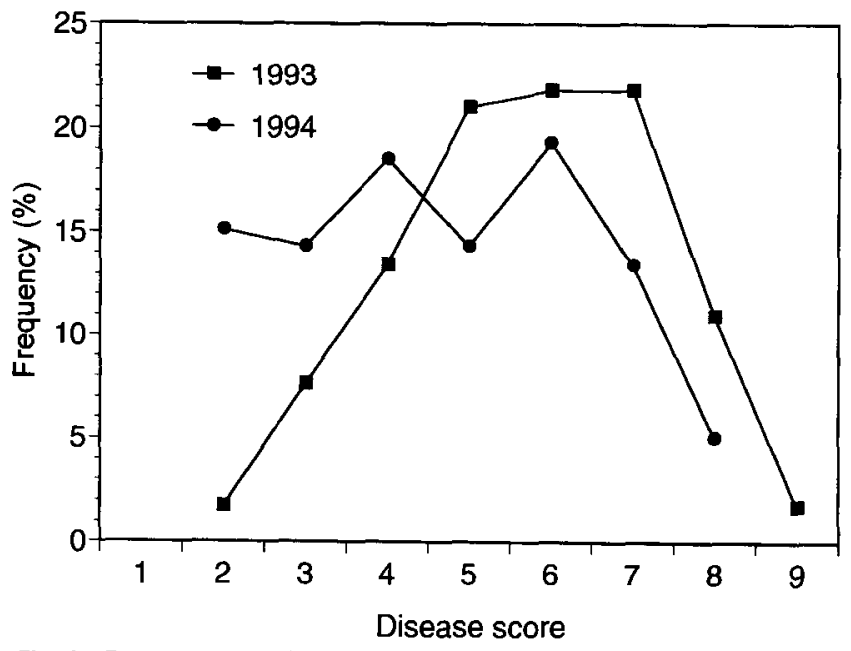

Fig. 1. Frequency distribution of the mean scores for ashy stem blight severity among 119 RILs (Dorado/XAN 176) field tested in two separate years ( $W$-tests for normality, $P>0.006$ in 1993 and $P<$ 0.001 in 1994). 
Table 2. Linkage group, estimated map distances between marker loci, and phenotypic variation in disease score associated with QTL identified by single-factor regression analysis $(P \leq 0.002)$ that condition field resistance to ashy stem blight in 79 F $_{5: 7}$ RILs (Dorado/XAN 176) tested two separate years.

\begin{tabular}{|c|c|c|c|c|c|c|c|}
\hline \multirow{2}{*}{$\begin{array}{l}\text { Linkage } \\
\text { group/QTL }\end{array}$} & \multirow{2}{*}{$\underset{\text { marker }{ }^{\text {RAPD }}}{\operatorname{Ra}}$} & \multirow[b]{2}{*}{ Allele $\ddagger$} & \multirow[b]{2}{*}{ Distance } & \multicolumn{2}{|c|}{1993} & \multicolumn{2}{|c|}{1994} \\
\hline & & & & $R^{2}$ & $\boldsymbol{P}$ & $R^{2}$ & $\boldsymbol{P}$ \\
\hline & & & cM & $\%$ & & $\%$ & \\
\hline \multirow{3}{*}{ US-6 } & Q11 $_{980}$ & $\mathbf{X}$ & & 15.5 & 0.000 & 12.5 & 0.001 \\
\hline & E19990 & D & 1.3 & 14.9 & 0.000 & 11.7 & 0.002 \\
\hline & $\mathbf{A S 8} 8_{1300}$ & D & & 12.3 & 0.002 & NS & \\
\hline \multirow{3}{*}{ US-7 } & $\mathbf{A H S}_{1370}$ & $\mathbf{x}$ & 10.0 & 17.7 & 0.000 & 14.8 & 0.0 \\
\hline & AA19 ${ }_{6000}$ & D & 4.9 & 19.0 & 0.000 & NS & \\
\hline & $\mathrm{AG10}_{\mathrm{g} \mathfrak{}}$ & D & & 14.8 & 0.000 & NS & \\
\hline \multirow[t]{2}{*}{ US-8 } & $\mathbf{W 1 2} 700$ & D & 5.7 & 12.7 & 0.001 & NS & \\
\hline & $\mathbf{F 1 0}_{1000}$ & $\mathbf{x}$ & & 11.5 & 0.002 & NS & \\
\hline Unlinked & $\mathbf{W 1 8}_{1390}$ & $\mathbf{X}$ & & 12.8 & 0.001 & NS & \\
\hline
\end{tabular}

† RAPD marker named for a specific Operon (Alameda, CA) decamer primer (number) from within a kit (letters). Number in subscript represents the base pair size of the marker.

₹ $D$ or $X=$ RAPD marker allele derived from Dorado parent or XAN 176 parent, respectively.

stem blight itself may have caused early maturity of severely infected lines. Conversely, a population mean skewed toward lateness (2.2) suggests lines expressing resistance may have experienced delayed maturity.

The frequency distributions of the $119 \mathrm{~F}_{5: 7}$ lines for mean disease score each year indicated a lack of discrete segregation classes (Fig. 1). Moderate heritabilities, 0.53 in 1993 and 0.57 in 1994, for disease score among $F_{5: 7}$ lines (Table 1), also indicated resistance within this population was quantitatively inherited. The significant deviation $(P<0.05)$ of the population mean from its midparent value, toward Dorado in 1993, may reflect a difficulty with recovering breeding lines with the same level of resistance of XAN 176.

Polygenic inheritance was further corroborated by RAPD marker analyses which revealed five independent QTL affecting disease reaction in 1993 (Table 2 and Fig. 2-5). These QTL on linkage groups US 4, US 6 , US 7, and US 8 and the unlinked marker W18 ${ }_{1300}$, respectively, explained $15,15,19,13$, and $13 \%$ of the phenotypic variation for disease score in 1993. Only the three QTL on US 4, US 6, and US 7, respectively explaining 12,12 , and $15 \%$ of the variation in disease reaction, were detected in 1994.

The regression and interval mapping analyses corroborated the relative effect of the identified QTL as RAPD markers associated with higher $R^{2}$ values also had higher LOD scores (Table 2 and Fig. 2-5). The three QTL on US 4, US 6, and US 7, had parallel response intervals between years, differing only by the magnitude of effect being greater in 1993 than 1994. The two significant peaks at $\mathrm{E} 19_{990}$ and $\mathrm{AS}_{1300}$ along US 6 apparently explain a single QTL, because when one locus was fixed the second locus had an LOD below 2.0. Perhaps including additional RILs in the mapping population would provide better resolution of this re-

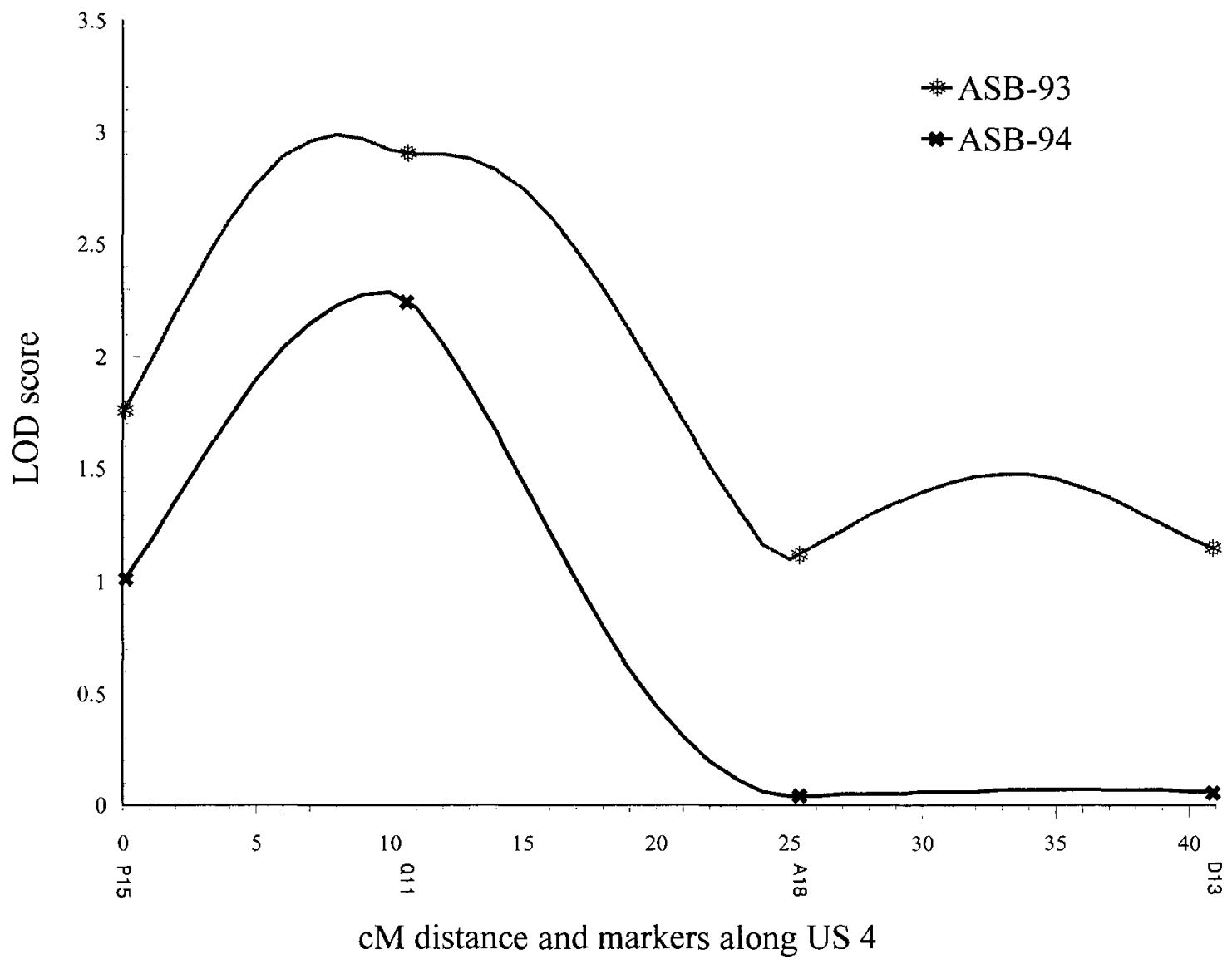

Fig. 2. Quantitative trait loci conditioning field resistance to ashy stem blight on linkage group US 4 as depicted by interval mapping (LOD 2.0) in 79 F $_{5: 7}$ RILs (Dorado/XAN 176) tested two separate years. 
gion along US 6 . The relatively flat interval reponse for US 8 in 1994 suggests that the QTL (W12 ${ }_{700}$ ) detected in 1993 will only be expressed in specific environments.

A few lines in 1994 had greater resistance $(P<0.05)$ than XAN 176. Recombinant inbred lines with QTLlinked RAPD alleles from XAN 176 had a reduced mean disease score and from Dorado an increased mean score both years, indicating none of the five QTL originated from Dorado. Thus, the transgressive segregation observed in 1994 could not be explained by the QTL we detected.

The entire map (900 cM), consisting of 147 RAPD markers assigned to ten linkage groups (US 1 to US 10), two linked triads (LT 11, LT 12), and seven linked pairs (LP 13 to LP 19) is described in detail by Miklas et al. (1998a). All the RAPD markers associated with QTL in this study fit segregation ratios (1:1) expected for undistorted markers.

Multiple QTL models $(P<0.01)$ explained up to $47 \%\left[\mathrm{Q} 11_{980}\right.$ (US 4) + AS $8_{1300}$ (US 6) + AA19 $9_{600}$ (US 7) + W12 $2_{700}$ (US 8)] of the phenotypic variation for disease score in 1993 and $28 \%$ [Q11 $1_{980}$ (US 4) + E19 $9_{990}$ (US 6) $+\mathrm{AH5}_{1370}$ (US 7)] in 1994. The effects of the QTL were mainly additive. Epistasis was detected $(P<0.05)$ between the US $4\left(\mathrm{Q} 11_{980}\right)$ and US 7 (AA19 ${ }_{600}$ ) QTL in 1993. The effect was positive, explaining an additional $4 \%$ of the phenotypic variation. Although a significant line $\times$ year interaction was detected $(P<0.05)$, with the exception of $\mathrm{W} 12_{700}$ on US 8 and the unlinked W18 1300 , the same QTL were expressed each year; however, they explained more of the variation in disease score in 1993 than 1994. Perhaps, less disease pressure contributed to the lower predictability of the multi-locus model in 1994. Interestingly the phenotypic variation explained by the 1993 model $(47 \%)$ approached the heritability estimate $(0.53)$, whereas they differed widely in 1994 ( $28 \%$ vs. 0.57$)$. It appears that selection in a single environment may be adequate if ideal disease pressure occurs to facilitate better separation of resistant and susceptible lines.

The quantitative inheritance of disease score in this population suggests high selection intensities, large pop-

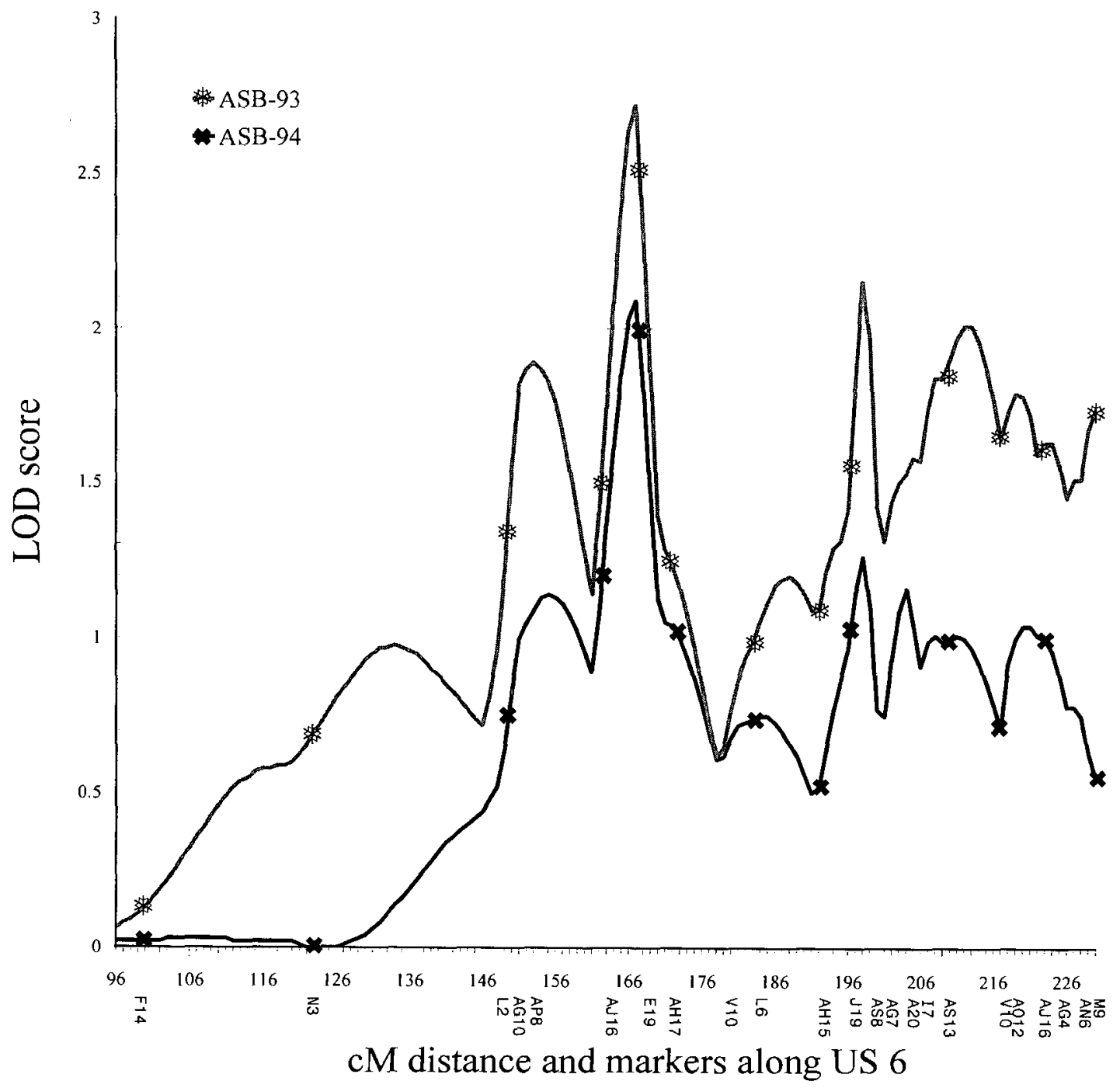

Fig. 3. Quantitative trait loci conditioning field resistance to ashy stem blight on linkage group US 6 as depicted by interval mapping (LOD 2.0) in 79 F $_{5: 7}$ RILs (Dorado/XAN 176) tested two separate years. 


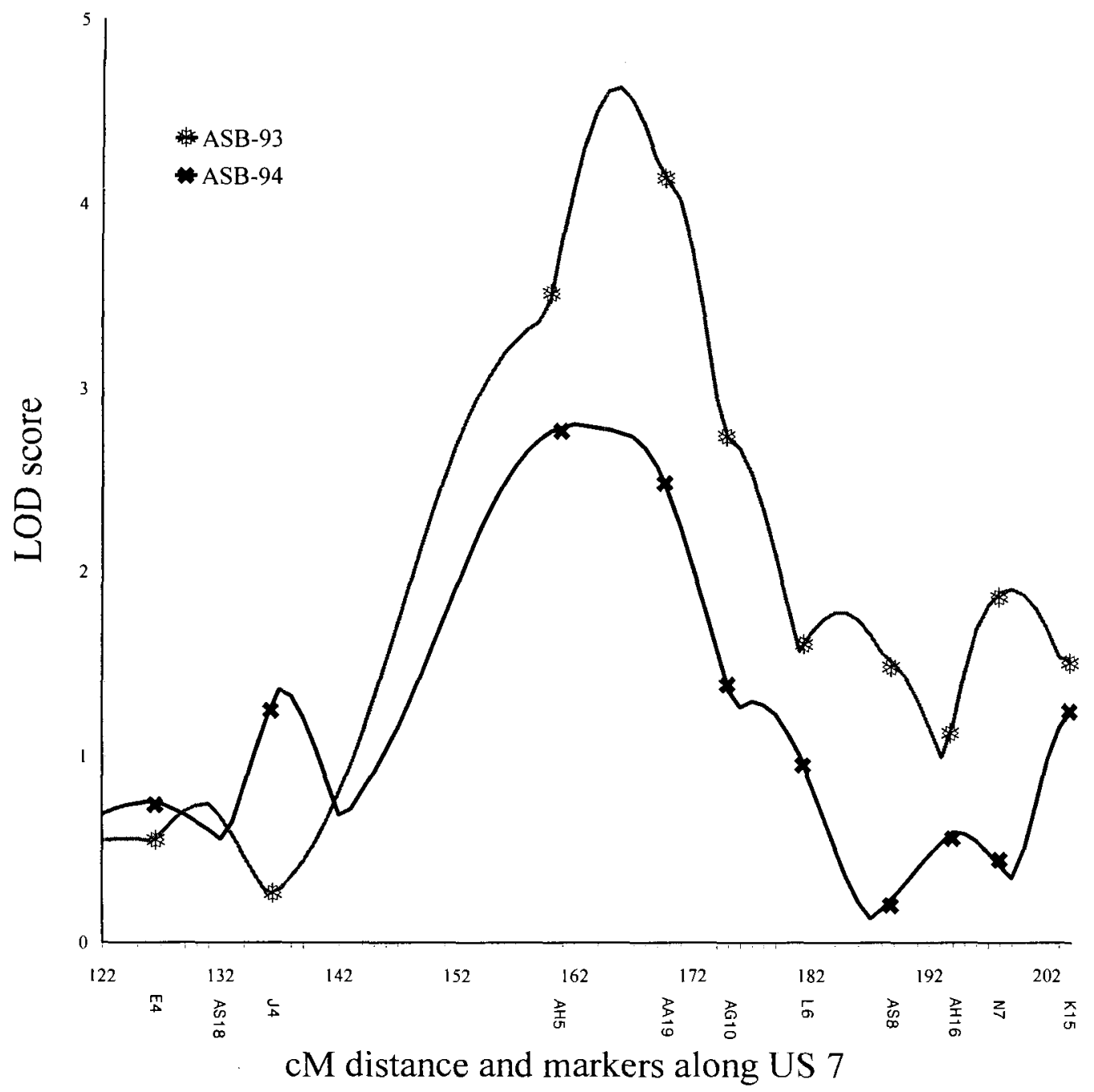

Fig. 4. Quantitative trait loci conditioning field resistance to ashy stem blight on linkage group US 7 as depicted by interval mapping (LOD 2.0) in $79 \mathrm{~F}_{577}$ RILs (Dorado/XAN 176) tested two separate years.

ulation sizes, and perhaps multiple environments will be required to phenotypically select for the XAN 176derived resistance to ashy stem blight segregating in other populations. Whether the RAPDs linked to these QTL will have utility for indirect selection of the XAN 176-derived resistance is unknown. Hybridization between a highly resistant inbred progeny line from this study and another susceptible cultivar would provide a useful population for assessing and confirming these QTL-linked RAPDs for marker-assisted selection.

For lasting control, combining quantitative resistance traits with qualitative resistance genes is preferred, but quantitative resistance is difficult to retain and is often lost in a traditional backcross breeding program to introgress major genes. The $M p-1$ and $M p-2$ resistance genes and linked RAPD markers from the breeding line BAT 477 (Olaya et al., 1996) have not yet been placed on a linkage map. Although it seems unlikely these QTL with relatively minor effects would be associated with major gene resistance, the relationship, if any, between $M p-1$ and $M p-2$ and the QTL identified in this study cannot be discounted. If independent, the markers for $M p-1$ and $M p-2$ and the QTL-linked RAPDs described herein would provide initial tools for testing markerassisted selection approaches to retaining and combining quantitative resistance traits with qualitative resistance genes for control of ashy stem blight in common bean.

\section{REFERENCES}

Abawi, G.S. 1989. Root rots. p. 105-157. In H.F. Schwartz and M.A. Pastor-Corrales (ed.) Bean production problems in the tropics, 2nd ed. Centro Internacional de Agricultura Tropical (CIAT), Cali, Colombia.

Abawi, G.S., and M.A. Pastor-Corrales. 1989. Charcoal rot screening procedure and virulence of Macrophomina phaseolina isolates on dry edible beans. Turrialba 39:200-207.

Abawi, G.S., and M.A. Pastor-Corrales. 1990a. Root rots of beans in Latin America and Africa: Diagnosis, research methodologies, and management strategies. Centro Internacional de Agricultura Tropical (CIAT) Bull. No. 35, Cali, Colombia.

Abawi, G.S., and M.A. Pastor-Corrales. 1990b. Seed transmission and effect of fungicide seed treatments against Macrophomina phaseolina in dry edible beans. Turrialba 40:334-339.

Beebe, S.E., and M.A. Pastor-Corrales. 1991. Breeding for disease resistance. p. 561-610. In A. Van Schoonhoven and O. Voysest (ed.) Common beans: Research for crop improvement. CAB Intl., Wallingford, UK.

Echavez-Badel, R., and J.S. Beaver. 1987. Resistance and susceptibil- 


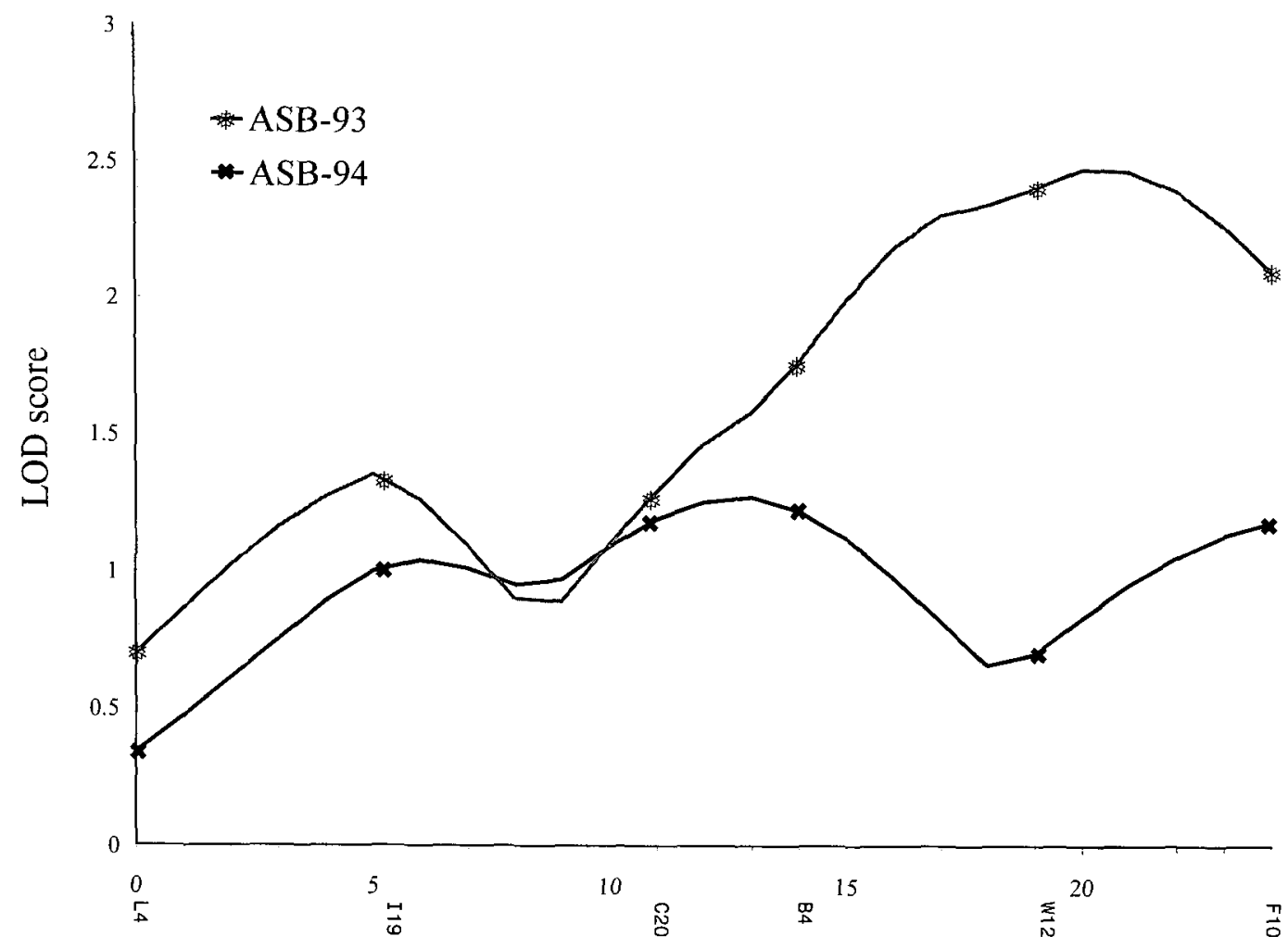

cM distance and markers along US 8

Fig. 5. Quantitative trait loci conditioning field resistance to ashy stem blight on linkage group US 8 as depicted by interval mapping (LOD 2.0) in 79 F $_{5: 7}$ RILs (Dorado/XAN 176) tested two separate years.

ity of bean to ashy stem blight. J. Agric. Univ. Puerto Rico 71: 403-406.

Hallauer, A.R., and J.B. Miranda. 1981. Quantitative genetics in maize breeding. Iowa State University Press, Ames, IA.

Knapp, S.J., W.W. Stroup, and W.M. Ross. 1985. Exact confidence intervals for heritability on a progeny mean basis. Crop Sci. 25: 192-194.

Kosambi, D.D. 1944. The estimation of map distances from recombination values. Ann. Eugen. 12:172-175.

Lander, E.S., P. Green, J. Abrahamson, A. Barlow, M.J. Daley, S.E. Lincoln, and L. Newburg. 1987. MAPMAKER: An interactive computer package for constructing primary genetic linkage maps of experimental and natural populations. Genomics 1:174-181.

Miklas, P.N., E. Johnson, V. Stone, J.S. Beaver, C. Montoya, and M. Zapata. 1996. Selective mapping of QTL conditioning disease resistance in common bean. Crop Sci. 36:1344-1351.

Miklas, P.N., R. Delorme, V. Stone, C.A. Urrea, J.S. Beaver, and J.R. Steadman. 1988a. A RAPD map of disease resistance traits in common bean. Annu. Rept. Bean Improv. Coop. 41:94-95.

Miklas, P.N., H.F. Schwartz, M.O. Salgado, R. Nina, and J.S. Beaver. 1998b. Reaction of select tepary bean to ashy stem blight and fusarium wilt. HortScience 33:136-139.
Nelson, C. 1996. QGene: Macintosh software for DNA-marker-based genetic analysis, version 2.26. Department of Plant Breeding and Biometry, Cornell University, Ithaca, NY.

Olaya, G., G.S. Abawi, and N.F. Weeden. 1996. Inheritance of the resistance to Macrophomina phaseolina and identification of RAPD markers linked to the resistance genes in beans. Phytopathology 86:674-679.

Pastor-Corrales, M.A., and G.S. Abawi. 1988. Reactions of selected bean accessions to infection by Macrophomina phaseolina. Plant Dis. 72:39-41.

SAS. 1987. SAS/STAT guide for personal computers, 6th Ed. SAS Institute, Cary, NC.

Schoonhoven, A.V., and M.A. Pastor-Corrales (ed.). 1987. Standard system for the evaluation of bean germplasm. Centro Internacional de Agricultura Tropical (CIAT), Cali, Colombia.

Schwartz, H.F. 1989. Additional fungal pathogens. p. 231-259. In H.F. Schwartz and M.A. Pastor-Corrales (ed.) Bean production problems in the tropics, 2nd ed. Centro Internacional de Agricultura Tropical (CIAT), Cali, Colombia.

Zaumeyer, W..., and H.R. Thomas. 1957. A monographic study of bean diseases and methods for their control. Tech. Bull. No. 868 . USDA, Washington, DC. 